\title{
Rights to forests and carbon under REDD+ initiatives in Latin America
}

Anne M Larson', Esteve Corbera², Peter Cronkleton', Chris van Dam³ , David Bray ${ }^{4}$, Manuel Estrada ${ }^{5}$, Peter May ${ }^{6}$, Gabriel Medina ${ }^{7}$, Guillermo Navarro ${ }^{8}$ and Pablo Pacheco'

\section{Key points}

- Rights to large areas of forest have been granted to communities and indigenous peoples in Latin America, offering these groups an opportunity to participate in REDD+ initiatives. However, tenure is not always secure, and security of tenure alone is insufficient to guarantee positive outcomes for both forests and livelihoods.

- The question of carbon tenure rights has only just begun to be addressed, and even less attention has been given to liabilities.

- REDD+ initiatives provide an opportunity to consolidate indigenous territories but present a risk to those without secure land rights.

- REDD+ initiatives should be informed by a clear understanding of the successes and failures of community forest management.

- REDD+ initiatives should recognise local diversity and not impose blueprints.

\section{Introduction}

Tenure rights over land, forest and carbon are of central concern to REDD+ strategies. Tenure rights shape access and decision making with regard to land and forest resources. Tropical forests, however, are often sites of conflict and competing claims to land and trees, and insecure forest tenure rights are associated with deforestation and degradation. Lowering carbon emissions and compensating those responsible under REDD+ initiatives will require clear and secure rights. This raises concerns for communities and indigenous peoples living in forests, who fear that REDD+ may lead to the usurpation of their rights by outsiders or to increased hardship due to new limitations on forest use.

Although the importance of these tenure issues is widely recognised, important gaps remain in the relevant literature and in country Readiness Preparation Proposals (R-PPs), particularly regarding the allocation of carbon rights and liabilities.

This brief is organised as follows. The first 2 sections discuss concepts of tenure and highlight progress and problems in the recognition or clarification of forest tenure in the Latin America region. The next section discusses community forestry management (CFM) as a potential REDD+ strategy. Following this is a discussion of indigenous territories specifically. The subsequent section presents the current status of country initiatives regarding rights, liabilities and benefit distribution. This is followed by a summary of the key lessons learnt and the conclusions.

\section{What are forest tenure rights?}

Land tenure systems are built on social relations. They include property rights, or enforceable claims, in favour of individuals, communities, organisations or the state. Rights-and, particularly, claims to rights-may emerge from formal legal systems, but they may also derive from customary systems or from the simple assertion of a claimant. Such claims, of course, may not be enforceable, leading to conflict over resources and tenure insecurity.

\footnotetext{
Center for International Forestry Research

School of International Development, University of East Anglia and Institute of Environmental Science and Technology (ICTA)

Autonomous University of Barcelona

Consultant Associate, Natural Resource Management and Rural Development, Intercooperation

Department of Earth \& Environment, Florida International University

Senior Consultant, Mexico

Department of Development, Agriculture and Society, Federal Rural University of Rio de Janeiro

Universidade Federal de Goiás, Escola de Agronomia, Setor de Desenvolvimento Rural, Goiânia

Centro Agronómico Tropical de Investigación y Educación
} 
Tenure rights are complex and multidimensional and are usually conceived of as 'bundles of rights'. The bundle includes rights to access or enter the area (access right); to use the land and withdraw resources (use right); to manage the landscape and plan for future use, such as tree planting or timber management (management right); to determine who can and cannot use resources (exclusion right); and to sell or transfer these rights to other parties (alienation right). On lands that are formally public or state property, which is often the case with forests, different people or groups may have one or more of these rights. The rights may be officially sanctioned by the state or they may be sanctioned in other ways such as by ancestral or customary claims.

Formal property ownership is usually classified as either public or private. The former refers to land that is formally owned by the state, and the latter often refers to a titled property in the name of an individual or entity. Communal or common property is located on land that is officially either state ${ }^{9}$ or privately owned (by the collective). Within a communal area, there may be both common and individual properties, but the rights-holder is the collective, and certain decisions or rules are likely to be made by collective institutions.

The types of tenure regime present in Latin American countries today have emerged from their respective colonial and postcolonial histories. Overall, approximately $74 \%$ of the global forest estate is owned and administered by governments, $14 \%$ is owned by individuals and firms, $9 \%$ is owned by communities and the remaining $2 \%$ is owned by governments but designated for use by communities (Sunderlin et al. 2008). In developing countries, however, the total percentage of forests managed by communities (owned or designated for their use) is much higher, at $27 \%$ in 2008. This is highest in Latin America, with 25\% owned by communities and indigenous peoples and $8 \%$ designated for their use (RRI 2009). See Box 1 for some examples.

Tenure rights are important for REDD+ initiatives. The forest tenure regime defines who is formally responsible for forest management or conservation policies and measures. Rights to

\section{Box 1. Forest tenure in 3 countries}

Reliable land and forest tenure statistics are notoriously difficult to obtain, and methods are not uniform across countries. Sometimes forest ownership statistics are available specifically and other times only land tenure data are available. For example, land tenure data are available for the Brazilian Legal Amazon but are often extrapolated to forest tenure. In the Brazilian Legal Amazon, private land comprises 24\% and public land, 76\%. Public land includes indigenous reserves, sustainable use areas (including extractive reserves), integral protected areas, land reform settlements and contested or undefined areas.

In Mexico, 3 categories of tenure system are recognised, private, public and 'social', with the latter referring to land owned by agrarian communities and ejidos. These 2 groups control more than half the land and $70 \%$ of the country's forests. Only $4 \%$ of forests are state owned and $26 \%$ are private.

In Costa Rica, forest cover data suggest that $40 \%$ of forests are in different kinds of protected areas with mixed ownership (22\% is in national parks and wilderness areas which are state-owned land, and $18 \%$ is in protected wild areas, which are mainly in the private domain), 50\% are on other private lands and 10\% are in indigenous reserves (see Table 1).

Table 1. Distribution of forests in 3 Latin American countries

\begin{tabular}{lccc}
\hline & Private (\%) & Public (\%) & $\begin{array}{c}\text { Community and } \\
\text { indigenous }\end{array}$ \\
$\begin{array}{l}\text { Mexico } \\
\text { Brazil (Legal Amazon } \\
\text { only) }\end{array}$ & 26 & 4 & 70 \\
Costa Rica & 24 & 43 & $33^{\mathrm{b}}$ \\
\hline
\end{tabular}

a. Community and indigenous lands may be on private or public lands, depending on the case. For Brazil and Costa Rica, these data may exclude additional forests on private, smallholder lands.; b. This includes indigenous reserves (21\%), extractive reserves (6\%) and land reform settlements (5\%); c. This includes $18 \%$ in protected wild areas that are mainly private lands.

Sources: Mexico: FAO (2010); Brazil: Lentini et al. (2005); Costa Rica: FCPF-Costa Rica (2010) 
carbon may or may not be tied directly to forest or land rights; it is therefore essential to determine who is entitled to (potentially tradable) carbon rights, and who is liable for future carbon losses. There has been much debate, though little resolution, regarding the distribution of rights and benefits. In contrast, there has been little discussion about the distribution of liabilities. On the one hand, if governments claim ownership over forest carbon, they are consequently assuming the responsibility for any future losses. On the other hand, if carbon rights are tied to land and forest rights, this may increase the likelihood of funds reaching community and indigenous rights-holders. This also implies that they could be held liable for any failure to reach long-term contractual commitments in terms of emissions reductions.

Finally, in light of REDD+, a discussion of community and indigenous rights to forests and carbon cannot be limited to a use right or even a decision-making right over a particular forest. Rather, it must include the right to participate fully in the design and implementation of a REDD+ strategy and/or a specific REDD+ project.

\section{Recognising community and indigenous rights in Latin America}

Latin America has a relatively high portion of forests under community management. This is partly because the region has gone furthest, in recent decades, in recognising the customary rights of forest-based peoples. For example, the portion of the Brazilian Amazon in the hands of communities and indigenous peoples (Table 1) constitutes some 135 million ha; in Bolivia, about 10 million ha in indigenous territories have been titled, and another 2 million ha have been titled to agroextractive communities; 39 million ha of forest are held by Mexico's ejidos and agrarian communities; and Colombia has titled more than 36 million ha, primarily in the Amazon. In Guatemala, 0.5 million ha of primary forest has been granted as community forest concessions to groups that did not necessarily have prior customary rights.

Forest tenure reform and policies favourable to communities have frequently emerged in response to grassroots mobilisation. In Mexico, the foundation for community tenure rights dates back to the Mexican Revolution and subsequent agrarian law, but more recent actions were decisive regarding forests. In 1982, in the state of Oaxaca, a combination of community protests, legal challenges and supportive professionals within the forest bureaucracy led to the overturning of a decision to renew logging concessions. Communities won the right to manage their own forests for the first time-a right that quickly spread throughout Mexico (Bray and Merino Perez 2004); in 1992, a legal reform removed the language granting the government 'primordial' rights over forests (Bray et al. 2006). Similarly, grassroots activism in Bolivia played an important role in pressuring the government to grant property rights over traditional territories to indigenous peoples, resulting in the passage of the agrarian reform law in 1996. Tenure policy reforms in the Brazilian Amazon also emerged partly in response to grassroots protests, beginning with the rise of the rubber tapper movement in the 1980s.

Implementing these tenure reforms has not always been easy, however, as government policymakers or implementing institutions may favour competing actors, prioritising the demands of economically powerful interests and industries over those of communities (Box 2). When state institutions do support community claims, they may use top-down approaches that fail to address complex webs of access to natural resources or to empower grassroots actors in their struggle to gain control over

\section{Box 2. Obstacles to implementing tenure rights reforms: The case of Bolivia}

Bolivia's agrarian reform law of 1996 established a process that allowed indigenous groups to petition for property rights as Original Community Lands (TCOs) and initiate titling. Titling has proven to be a long and drawn-out process. Of the 60 TCO claims in the forested lowlands, 30 had received no titles after 10 years; of the 30 that have been at least partially titled, the titled area accounted for less than half of the 9.6 million ha requested (CIDOB/CPTI 2008). Although the government officially 'immobilises' competing claims, in practice indigenous residents have had to struggle to maintain control over territory while the Agrarian Reform Institute evaluates third-party claims. For example, in the Guarayos $\mathrm{TCO}$, in just one section being titled, 44 fraudulent transactions, involving private landowners, indigenous leaders and government employees, were identified in 2004. It was estimated that more than US\$ 1 million changed hands (López 2004, Moreno 2006).

Similarly, the forest property rights of non-indigenous agroextractive communities in Bolivia's northern Amazon were not immediately addressed by the country's agrarian reform. In 2000, members of the regional elite, known as barraqueros, lobbied the government for rights to more than 3 million ha of non-timber forest product (NTFP) concessions; this benefited only about 200 people and denied rights to the vast majority of the local population in rural communities (Aramayo Caballero 2004). The barraqueros' petition, which was initially granted by presidential decree, was overturned only after significant local and regional protest. 
resources. When local action shapes the types of rights granted, community rights are more likely to be respected.

Secure tenure may be a prerequisite for the successful implementation of REDD+ projects, but recognising or clarifying local rights is not, by itself, a panacea either for forests or for local livelihoods. Land titles, for example, do not automatically stop land invasions or competition over resources. Therefore, additional efforts will be required to guarantee rights in practice. However, local actors with secure rights may then choose to deforest if alternative land uses are more profitable. At the same time, local livelihoods may not improve if regulations restrict forest use; in some cases, what is needed is not tenure clarity but rather greater rights to the use and trade of forest resources. Better outcomes for both forests and livelihoods are more likely when tenure reforms are accompanied by policies that create enabling conditions for local forest management.

\section{Community forest management as an option for REDD+}

Community forest management (CFM) is one strategy by which, through collective action, local people can move beyond deforestation and degradation and achieve sustainable management. CFM has probably had as many failures as successes, but with appropriate learning from existing models and experiences, CFM may be an effective, efficient and equitable means for reducing emissions from deforestation and degradation under REDD+ initiatives. CFM is broadly defined here as the management of forest resources and services by selfdefined communities ${ }^{10}$ under shared rules or collective rights.

There is evidence that local forest management can be good for forests. Brazilian indigenous territories halted deforestation despite high rates of forest clearance along the boundaries (Nepstad et al. 2006). Brazil's Alto Juruá Extractive Reserve maintains 99\% forest cover after a decade (Ruiz-Pérez et al. 2005). In Nicaragua, areas of the Bosawas Reserve under indigenous control show deforestation rates 16 times lower than in surrounding areas (Stocks 2007). A global analysis based on data from 80 community forests suggests that improvements in both livelihoods and carbon storage are more likely if local people are granted greater rights to make local rules about the use of forests (Chhatre and Agrawal 2009).

CFM takes many different forms across Latin America, involving timber, non-timber forest products (NTFPs) and forest environmental services, and has emerged under a variety of circumstances. The following cases refer specifically to logging.

In Mexico, the agrarian law led to waves of land distribution throughout the $20^{\text {th }}$ century that established communal property rights systems in forests. Hence agrarian reform laid the territorial and governance foundation for the establishment of a large community forestry sector. CFM came later, however, because forest management remained the jurisdiction of the central government until the 1980s. Today, approximately 2300 communities have some regulated logging activities, and some 600 in the 10 most important forested states have achieved some degree of vertical integration, from skidders to sawmills and furniture factories (Bray et al. 2007). In Sierra Norte, in the state of Oaxaca, many communities have diversified into community ecotourism, water bottling and payments for environmental services (PES). These experiences present a 'post-REDD' landscape - that is, the landscape anticipated after successful REDD+ implementation-achieved without benefit of forest carbon financing, although with government and NGO support.

In Brazil and Bolivia, property and forest management rights have been devolved more recently and almost simultaneously in each country. In Brazil in 1996, the government programme ProManejo established pilot forest management activities in 24 Amazonian communities. Many of these initiatives were highly subsidised. Although community members participated in some activities, external foresters generally controlled the conception and definition of the management approach. Because they depended on subsidies and unfamiliar concepts, the CFM models being tested were not adopted by neighbouring communities and often collapsed once external support was removed (Medina et al. 2009). New efforts for CFM that draw on lessons from these experiences are emerging from grassroots and joint community-government initiatives to identify and build on traditional forms of timber use and local governance.

In Bolivia, CFM for timber has played an important role in helping indigenous people consolidate their rights over forests while land claims are in the process of demarcation and titling. One of the more successful cases involves the community of Cururú in the Guarayos territory in the province of Santa Cruz. Cururú is a small, remote village that had some prior experience with logging but not with administering logging operations. It received support from a forestry development project and NGOs to develop a management plan. The community began by selling standing trees, and later took control of felling in order to generate jobs for residents. In 2007, it received Forest Stewardship Council certification and developed partnerships with certified timber industries in Guarayos to improve markets. Cururú's remote location meant the community had time to consolidate its management organisation before other actors moved into the region.

Conditions for successful REDD+ initiatives are similar to those that are conducive to successful CFM, beginning with secure property rights over forest resources. The control, administration and use of forest resources, however, require strong governance institutions at multiple scales, based on a solid foundation at the community level. Successful cases suggest the importance 
of gradual and continuous learning processes to ensure sustainability in the long term.

\section{REDD+ in indigenous territories: Threat or opportunity?}

An important proportion of Latin America's forests are located in indigenous territories. Indigenous peoples are the beneficiaries of about $85 \%$ of the area to which local rights to land and forest have been recognised in Latin America since the 1980s. Nevertheless, many of these areas, regardless of whether rights have been recognised, are subject to threats from colonists, illegal loggers, mining and oil interests and others, whose practices endanger not only the forests but also indigenous peoples' territory as a whole. In this context, REDD+ could constitute a new threat or intensify others, particularly in places where rights have not been recognised. REDD+ could also offer new opportunities.

Today, 375 indigenous peoples hold 25.3\% of the Amazon region. If this is combined with protected areas, many of which are also home to indigenous peoples, this area increases to $41.2 \%$ of the total (Benavides 2009; Table 2). Indigenous territories are substantively different from the communities and territories of non-indigenous groups. In particular, indigenous peoples' rights are protected in international conventions (e.g. UN Declaration on the Rights of Indigenous Peoples), and their right to territory is embedded in a series of other collective rights such as the right to autonomy or self-government, to natural resource management and to free prior and informed consent (FPIC).

Indigenous territories also constitute a new spatial unit that is quantitatively and qualitatively different from earlier emphases on 'community'. The territorial scale is more compatible with
Table 2. Indigenous territories in the Amazon

\begin{tabular}{lc}
\hline Country & \% of the country's Amazon \\
\hline Bolivia & 25.7 \\
Brazil & 21.7 \\
Colombia & 56.0 \\
Ecuador & 64.8 \\
French Guyana & 7.3 \\
Guyana and Suriname & no data \\
Peru & 16.7 \\
Venezuela & 67.4 \\
Total Amazon & 25.3 \\
\hline
\end{tabular}

Source: Benavides (2009)

managing the drivers of deforestation and degradation and providing REDD+ compensation. It may offer a solution to the problems of limited scale and profitability associated with small CFM operations. At the same time, the territory represents a new scale of operation, at which most indigenous communities do not have governance institutions. This is complicated further by the diversity within territories, which may include a variety of communities and even ethnic groups. In addition, the vast diversity among territories (Box 3) suggests a need for different approaches in different contexts.

REDD+ potentially offers support for the constitution of these territories as political, social and economic entities; this is particularly true if approaches include co-benefits rather than being limited to carbon emissions. REDD+ policies that address the external drivers of deforestation will in many cases also be addressing the primary threats to the integrity of indigenous territories. REDD+ provides a new source of value to forests that could lead to increased and diversified income for indigenous

\section{Box 3. Territorial diversity}

The following factors are important for understanding the dynamics of any particular territory:

- size, fragmentation and connectivity or accessibility between communities

- multiethnic character, number of communities and location within the territory

- above-soil and sub-soil natural resource endowments

- existing and latent threats from other actors

- partial or total overlap with protected areas, border conflicts with neighbours and legal security over the territory

- relevance of traditional or customary forms of organisation, administration of justice, knowledge and practices

- market ties, as well as ties to other external institutions

- migration patterns, influence of urban-based indigenous families and presence of non-indigenous actors

- existence of land use plans, 'life plans' (developed by some indigenous organisations in Ecuador and Colombia) or any other planning document from a territorial perspective

- political, legal and economic frameworks of each country, which shape legal security and economic conditions 
peoples while allowing them to continue with many traditional livelihood activities. These opportunities are more likely to be realised in territories where rights are already secure.

Where indigenous rights to territory have not been formally recognised, or where demarcation is still underway, more powerful actors might compete for these forests because of their new value as carbon reservoirs. Large new sources of income could encourage governments to recentralise forest governance, make new demands on indigenous peoples and even call for their expulsion from the forest if they fail to follow rules (Phelps et al. 2010).

Indigenous peoples also face challenges with regard to REDD+, although these should not be used as an excuse to avoid working in indigenous territories. First, it can be difficult for indigenous communities to comply with formal contracts, particularly if they have weak negotiating capacities or are relatively isolated with little market experience. An externally imposed contract can be very restrictive. Given the heterogeneity of territories and their recent configuration, each REDD+ contract should be built around the local institutions and practices of the relevant territory. Contracts should be realistic and transparent, and they should incorporate the flexibility of adaptive learning processes.

Second, collective governance of income requires a certain level of administrative and organisational capacity. This will vary by territory. In many cases, important investments should accompany REDD+ to build financial management capacity, equity and transparency in the context of indigenous selfgovernment. Emphasis should be on building sustainable institutional structures at the territorial scale for the long term, based, where possible, on traditional forms of representation and decision making.

\section{Carbon rights, liabilities and benefit distribution: Unanswered questions}

Several unanswered questions remain regarding the allocation of rights and liabilities, and accountability in trade and benefit sharing, under REDD+ initiatives. A 3-country analysis (Corbera et al. in press), of Brazil, Costa Rica and Mexico, demonstrates multiple and complex tenure regimes emerging from particular historical processes and policies regarding the ownership and transformation of land. These regimes and their evolutionary contexts should be the starting point for designing policies to increase carbon stocks and economic benefits for rights-holders. Following are 2 such unanswered questions.

\section{Will carbon rights be linked to land ownership or will} the government retain carbon rights? Land tenure and carbon rights and liabilities may be linked or separated, with direct implications for rural development. If rights are linked, landowners would experience an increase in the value of their land and could potentially obtain a new source of income, but presumably would also become directly liable for future carbon losses. If carbon rights are delinked and carbon is considered a public, state-controlled commodity, landowners are likely to be subject to greater state regulation on land use, incentives to rural actors may only be indirect or partial, and the state would be held responsible for liabilities before the international community. These issues are particularly important to address in light of a future anticipated compliance market, though they are less crucial for current voluntary markets.

The analysis of REDD+ strategies (R-PPs) from Brazil, Costa Rica and Mexico finds that all 3 tend towards linking formal land ownership with carbon rights. Nevertheless, both Mexico and Costa Rica establish a clear legal framework through which forest users can claim and benefit from carbon rights, while the state claims carbon rights in forests under its exclusive management. Legislation is currently under debate in Brazil. Less attention has been given to the issue of carbon liabilities; neither the Mexican nor the Costa Rican strategy discusses penalties or community rights if third parties fail to meet contract agreements. Nor do these R-PPs include sufficient detail about government plans to address persistent tenure insecurities, or ongoing and potential new conflicts in forestlands. In particular, new conflicts may arise from the increase in forest value resulting from carbon trading.

\section{Who is entitled to carbon rights in communal lands and} indigenous territories? In collectively owned properties, such as the indigenous territories mentioned above, additional issues arise regarding the distribution of rights and liabilities. Early evidence from carbon forestry projects suggests that revenues may be distributed in favour of households with greater available capital, disposable income and active participation in project activities, to the detriment of those who lack resources but still hold rights over collective forests (Corbera et al. 2007).

In the design and development of REDD+ strategies and projects, insufficient attention has been given to the particular issues of collective, community and indigenous lands and rights. These issues concern the following 4 specific arenas.

1. Few countries have ensured the participation of indigenous and rural communities, or at least their representatives, from the start in designing REDD+ strategies across governance scales (Davis et al. 2010a, 2010b). There are not yet clear procedures in Mexico or Costa Rica for indigenous and community participation in shaping REDD+ policies and measures, which are already fairly well defined.

2. When REDD+ options are implemented by rural communities, substantive information will be required regarding why and where REDD+ activities should be developed and who is entitled to carbon and its corresponding benefit streams.

3. Current strategies do not address the distribution of incentives within forest communities. This is overlooked in part because communities are perceived as having their own legitimate systems of benefit sharing; however, experience demonstrates that these systems are not always equitable. 
This inevitably raises difficult questions regarding the role of external actors in internal governance systems.

4. REDD+ options could have perverse impacts on local culture and future attitudes towards conservation. Schemes such as PES are still new and inconclusive. Therefore, it would be a risk to make a considerable part of REDD+ success conditional on PES performance (see, for example, Van Hecken and Bastiaensen 2010).

\section{Lessons learnt}

- National forest tenure regimes and the exercise of forest rights are highly diverse and complex. To be effective and equitable, REDD+ will require an understanding of this complexity.

- In the past, many community forestry models have failed to take local institutions into account; rather, they have been introduced through blueprint approaches. REDD+ initiatives will be more successful and obtain more local support if they are based on local institutions and build on local experience.

- Carbon rights and liabilities add a new layer of complexity to an already complex situation of rights and will have to be clarified for REDD+ to be successful.

- Where local people do not have secure rights to their land, more powerful competitors may threaten their rights in the interest of obtaining income from REDD+.

- Experience with CFM suggests that communities and indigenous people will be more willing to engage with REDD+ initiatives, and not to oppose them, if they participate in the design and implementation of strategies and projects and if they are granted secure rights to the carbon in their forests.

- Communities are more likely to oppose outside initiatives if rules are imposed upon them, rather than designed locally.

- Adaptive and flexible models permit initiatives that are based on the specific characteristics of each community or territory, and include capacity building directed to its particular needs. Such methods are more likely to lead to effective and sustainable outcomes.

- Projects in indigenous territories sometimes fail to accept already recognised indigenous peoples' rights to territory, to self-government and to FPIC. Territorial governance may require outside support but should be aimed at building internal capacity for self-government over the long term.

- New initiatives such as REDD+ could create new value for forests at the expense of traditional livelihood practices or the multifaceted meaning of forests for indigenous peoples. Instead, finding a balance between the reproduction of traditional lifestyles and the possibilities of market articulation could avoid conflict and promote economic, social and cultural sustainability.

\section{Conclusions}

REDD+ initiatives will need tenure issues to be resolved, so that the distribution of rights and obligations is clear. Communities living in forests that do not currently have secure rights are concerned that REDD+ represents a threat to their livelihoods, as others may gain rights to the resources on which they depend. At the same time, rights to large areas of forests in Latin America have been granted to communities and indigenous peoples. Even in these areas, however, ongoing threats and competing interests often undermine the consolidation of those rights. REDD+ could constitute a new threat; alternatively, if it is implemented in ways that are compatible with and respectful of the diversity of local needs and interests, it could offer an opportunity for new support for sustainable livelihoods and the defence and consolidation of territory.

\section{References}

Aramayo Caballero, J. 2004 La reconstitución del sistema barraquero en el Norte Amazónico: Análisis jurídico del Decreto Supremo No. 27572. CEJIS, Santa Cruz, Bolivia.

Benavides, M. 2009 Economía indigena y bosque Amazónico. Paper to the Encuentro Internacional de Pueblos indígenas y Lideres Locales para la Defensa de Derechos y Conservación de Bosques, AIDESEP. Lima, Peru, 2-3 April.

Bray, D.B. and Merino Perez, L. 2004 La experiencia de las comunidades forestales en México: Veinticinco años de silvicultura y construcción de empresas comunitarias. Instituto Nacional de Ecología (INI-SEMARNAT), Mexico City, Mexico.

Bray, D.B., Antinori, C. and Torres-Rojo, J.M. 2006 The Mexican model of community forest management: the role of agrarian policy, forest policy, and entrepreneurial organisation. Forest Policy and Economics 8: 470-484.

Bray, D.B., Durán Medina, E., Merino Pérez, L., Torres Rojo, J.M. and Velázquez Montes, A. 2007 Nueva evidencia: los bosques comunitarios de México protegen el ambiente, disminuyen la pobreza y promuevan la paz social. Agrupación Sierra Madre/Consejo Civil Mexicano para la Silvicultura Sostenible, Mexico City, Mexico.

Chhatre, A. and Agrawal, A. 2009 Trade-offs and synergies between carbon storage and livelihood benefits from forest commons. Proceedings of the National Academy of Sciences. 106(42): 17667-17670.

Confederación de Pueblos Indígenas de Bolivia/Centro de Planificación Territorial Indígena (CIDOB/CPTI) 200810 anos San-TCO: la lucha por los derechos territoriales indígenas de tierras bajas Bolivia. CIDOB/CPTI, Santa Cruz de la Sierra, Bolivia.

Corbera, E. Estrada, M., May, P., Navarro, G. and Pacheco, P. [in press] Rights to forests and carbon: insights from Mexico, Brazil and Costa Rica. Forests. http://www.mdpi.com/ journal/ forests (20 November 2010). 
Corbera, E., Brown, K. and Adger, W.N. 2007 The equity and legitimacy of markets for ecosystem services. Development and Change 38(4): 587-613.

Davis, C., Nakhooda, S. and Daviet, F. 2010a Getting ready. A review of the World Bank Forest Carbon Partnership Facility readiness preparation proposals, v 1.3. WRI Working Paper. World Resources Institute, Washington DC. http://www.wri.org/gfi

Davis, C., Williams, A., Goers, L., Daviet, F. and Lupberger, S. 2010b Getting ready with forest governance. A review of the World Bank Forest Carbon Partnership Facility readiness preparation proposals, v.1.4. WRI Working Paper. World Resources Institute, Washington DC. http://www.wri.org/gfi

Food and Agriculture Organization (FAO) 2010 Evaluación de los Recursos Forestales Mundiales. National Report, Mexico City, Mexico. http://www.fao.org/forestry/ 20262-1-176.pdfUNFCCC

Forest Carbon Partnership Facility-Costa Rica (FCPF-Costa Rica) 2010 Readiness preparation proposal review: Costa Rica. Reviewer: Eduardo Morales and Sandra Brown, et al. Date of review: 19 August 2010.

Lentini, M., Pereira, D., Celentano, D. and Pereira, R. 2005 Fatos Florestais da Amazônia. Instituto do Homem e Meio Ambiente da Amazônia, Belém, Brazil.

López, G.R. 2004 Negociaron tierras fiscales en la TCO de Guarayos. El Deber, 7 November, Santa Cruz de la Sierra, Bolivia.

Medina, G., Pokorny, B. and Campbell, B. 2009 Community forest management for timber extraction in the Amazon frontier. International Forestry Review 11: 408-420.
Moreno R.D. 2006 COPNAG denuncia la venta en \$us 1,2 millones de TCO en Guarayos. El Deber, 27 November, Santa Cruz de la Sierra, Bolivia.

Nepstad, D., Schwartzman, S., Bamberger, B., Santilli, B., Ray, D., Schlesinger, P., Lefebvre, P., Alencar, A., Prinz, E., Fiske, G. and Rolla, A. 2006 Inhibition of Amazon deforestation and fire by parks and indigenous lands. Conservation Biology 20(1): $65-73$.

Phelps, J., Webb, E. and Agrawal, A. 2010 Does REDD+ threaten to recentralize forest governance? Science 328(5976): 312-313.

Rights and Resources Initiative (RRI) 2009 Tropical forest tenure assessment: trends, challenges and opportunities. Occasional Paper No. 47. http://www.rightsandresources. org/documents/files/doc_1075.pdf

Ruiz-Pérez, M., Almeida, M., Dewi, S., Lozano Costa, E.M., Ciavatta Pantoja, M., Puntodewo, A., de Arruda Postigo, A. and Goulart de Andrade, A. 2005 Conservation and development in Amazonian extractive reserves: the case of Alto Juruá. Ambio 34(3): 218-223.

Stocks, A., McMahan, B. and Taber, P. 2007 Indigenous, colonist, and government impacts on Nicaragua's Bosawas Reserve. Conservation Biology 21(6): 1495-1506.

Sunderlin, W.D., Hatcher, J. and Liddle, M. 2008 From exclusion to ownership? Challenges and opportunities in advancing forest tenure reform. Rights and Resources Initiative, Washington, DC.

Van Hecken, G. and Bastiaensen, J. 2010. Payments for cosystem services in Nicaragua: do market-based approaches work? Development and Change 41(3): 421-444.

This summary was drawn from three papers: 1) Rights to forests and carbon Insights from Mexico, Brazil and Costa Rica; 2) Indigenous territories and REDD in Latin America: Opportunity or threat?; 3) Community forest management and REDD+ development: Lessons from Mexico, Bolivia and Brazil. They were prepared for the 'Workshop on forest governance, decentralisation and REDD+ in Latin America and the Caribbean', Oaxaca, Mexico, 31 August - 3 September 2010. The workshop was a country-led initiative in support of the United Nations Forum on Forests (UNFF) (http://www.cifor.cgiar.org/Events/Oaxacalist/introduction.htm). The full papers will be published in a special issue of Forests, an open access journal of forestry and forest ecology: http://www.mdpi.com/journal/forests.
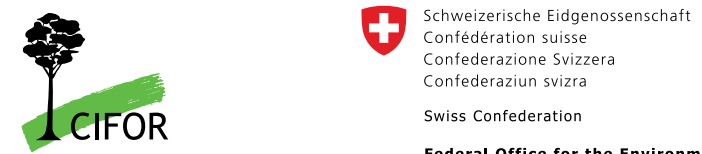